\section{Hard graft in the vineyards}

Cyril Ray

The Great Wine Blight. By George Ordish. Sidgwick and Jackson: 1987. Pp.246. £12.95.

Writing in the $1930 \mathrm{~s}$, Winston Churchill recalled that it was in 1898 , waiting to go into action on the North West Frontier, that he overcame his "repugnance to the taste of whisky ... of course all this whisky business was quite a new departure in fashionable England. My father for instance would never have drunk whisky except when shooting on a moor ... he lived in the age of the "brandy and soda'" This merits a footnote in the social history of England, as, in the history of France, do the champagne riots of 1911; then, for nine months of violence and military law, the wine-growers were outnumbered by regular troops, horse and foot.

The social rise of whisky and, thanks to the riots, the existing rigorous laws that govern the production of champagne were indirectly brought about by a bug discovered in a Hammersmith greenhouse in 1863 - Phylloxera vastatrix. It ravaged the vineyards of France from then until the turn of the century, costing the country, it is seriously estimated, more than the
Franco-Prussian war

The phylloxera, which destroys the roots of the European vine, Vitis vinifera, swept northwards through France, reaching the Cognac region in about 1875 , Champagne in 1890; by the time of which Churchill wrote. British stocks of prephylloxera brandy had run low, and were being augmented with spirits made from who knows what, or stuff chemically 'improved'. At the same time it became legal to blend the aromatic single-malt whisky with more nearly neutral grain whisky, to produce a lighter drink suited, with soda, for the drawing-room, leaving single malts for the grouse-moor.

George Ordish was not only producing wine in Kent 50 years ago but for at least as long has been one of Britain's greatest authorities on pest control. In this book, first published in 1972, he does not neglect such social consequences as this of the phylloxera plague. But in the main he recounts in scholarly fashion the many chemical and other remedies that were tried and found wanting for half a century or so from the $1860 \mathrm{~s}$, until it was shown that the classic vines of Europe, producing fine wines, would go on doing so after being grafted on to the root-stock of native American vines, producing wines that were far from fine but were resistant to the phylloxera.

So far, so good. The last chapter of this revised edition, however, brings the dread news that a new, sturdy strain of phylloxera has appeared in many parts of the world - even in the United States, whence had come what had been thought to be salvation.

Tiny vineyards exist where ungrafted vines still flourish. In Champagne, the distinguished house of Bollinger has two half-hectare plots where ancient vines are "layered" to send out roots each spring from buried branches. Since 1969, at my suggestion, Bollinger have made wine from these vines separately from the others, but Mr Ordish will be disappointed in the hope (expressed on p.137) that this would make possible a comparison between wines from ungrafted and from own-roots vines but of the same varieties of grape from the same soil. Not so: since 1974 the pre-phylloxera wines, in exceptional years, and at necessarily high prices, have been sold as Bollinger Vieilles Vignes Françaises, and show themselves deeper in colour and in flavour than Bollinger's other wines. But this could well be, if only partly, because the ancient vines are all Pinot Noir, providing that champagne rarity, a blanc de noirs, whereas all other champagnes are a blend of black grapes and white - mostly black - or the lighter blanc de blancs.

Cyril Ray, Albany, Piccadilly, London WIV $9 R Q, U K$, formerly a war correspondent and foreign correspondent, is author of Bollinger: The Story of a Champagne (1971) and The Wines of France (1976) among many other books on wine.
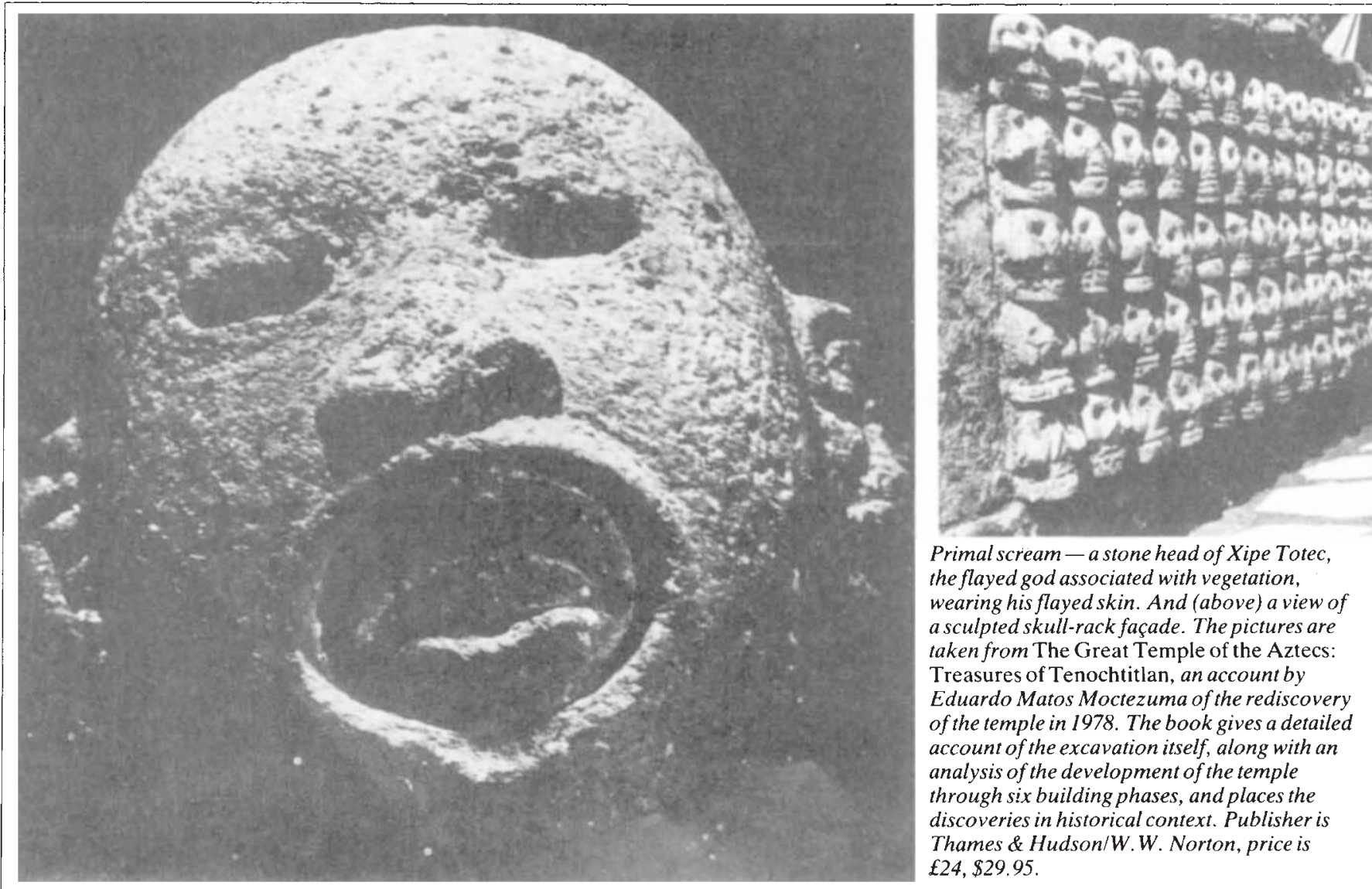